Article

\title{
Managing Nature-Business as Usual: Resource Extraction Companies and Their Representations of Natural Landscapes
}

\author{
Mark Brown \\ Received: 20 July 2015; Accepted: 24 November 2015; Published: 30 November 2015 \\ Academic Editor: Md Saidul Islam \\ Department of Communication and Culture, BI Norwegian Business School, \\ Nydalsveien 37, 0484 Oslo, Norway; mark.brown@bi.no; Tel.: +47-4641-0698; Fax: +47-2326-4781
}

\begin{abstract}
This article contributes to knowledge of how one category of business organization, very large, British-based, natural resource extraction corporations, has begun to manage its operations for sustainability. The object of study is a large volume of texts that make representations of the managing-for-sustainability practices of these multinational corporations (MNCs). The macro-level textual analysis identifies patterns in the wording of the representations of practice. Hajer's understanding of discourse, in which ideas are contextualized within social processes of practice, provides the theoretical approach for discourse analysis that gives an insight into how they understand and practice sustainability. Through this large-scale discourse analysis, illustrated in the article with specific textual examples, one can see that these natural resource MNCs are developing a vocabulary and a "grammar" which enables them to manage natural spaces in the same way that they are able to manage their own far-flung business operations. They make simplified representations of the much more complex natural landscapes in which their operations are sited and these models of nature can then be incorporated into the corporations' operational management processes. Their journey towards sustainability delivers, in practice, the management of nature as business continues as usual.
\end{abstract}

Keywords: sustainable development; corporate sustainability; operating management; managing nature; discourse

\section{Introduction}

Although the term sustainable development had then been in wide circulation for almost two decades, Dryzek [1] insisted in 2005 that it still referred "not to any accomplishment, still less to a precise set of structures and measures to achieve collectively desirable outcomes" but that it remained "a discourse". Another decade on, and confirming his view that meanings of the term are still being explored, this special issue of Sustainability will provide "an environmental sociology approach to understanding and achieving the widely used notion of sustainability" [2]. The particular focus of this article is on how business corporations with a commitment to sustainable development are beginning to understand what sustainability means for them and what their particular practice of the term is achieving.

For some time already, scholars have expressed their misgivings that the corporations' implementation of what they choose to call sustainability is not that at all. In 2004, Gray and Milne [3] point out that triple-bottom-line (TBL) accounting is in danger of being confused with sustainability reporting, a key argument for which is the organization-level vs. system-level perspective that separates the two. In 2010, Gray's [4] literature survey is able to observe that "most business reporting on sustainability and much business reporting on activity around sustainability has little, if anything, 
to do with sustainability" (p. 48). Nine years later, in 2013, Milne and Gray [5] question whether TBL is helpful at all in moving us towards sustainability. I shall discuss these misgivings in the methodological rationale. My own view is that such terms as sustainability start their lives as labels for new ideas that will move the arguments forwards. Then meanings (plural) develop as a consequence of practices (plural) - both intellectual and behavioral. We can learn about how the term is being understood by its practitioners, as we study their practice; and there may be value in that knowledge. Understanding how business corporations might move towards more sustainable modes of operation is one of many research projects within environmental sociology. However, according to a leading researcher, scholars have not yet developed comprehensive theories for sustainability management; we do not have a clear view of where to get to or how to get there [6].

Shifting focus from "there" to "here", knowledge about how far business has gotten in managing for sustainability is also in short supply. In a recent article reviewing research in the field, Zollo, Cennamo, and Neumann [7] observe that a great deal of research effort to date has been allocated to the two "broad sets of questions: why should companies move beyond serving merely economic purposes and what makes a company more sustainable" (p. 242). As a supplement to work on the theoretical, long-term models, they argue, we should also study the stepwise process of organizational evolution towards sustainability i.e., where "sustainable" business practice is now and where it may be going. This article makes a contribution to knowledge of how one category of business organization, very large, British-based, natural resource extraction corporations, has begun to manage its operations for sustainability.

\section{Hypothesis Development}

The corporations in the object of study include British Petroleum, Rio Tinto, Shell, and Anglo-American, (see Section 4. Method for details of selection criteria). These companies have made public commitments to pursuing a sustainable future and they make use of nature both in terms of resource extraction and as a sink for unwanted byproducts of production processes. Their intention to move towards "sustainable" modes of operation means that they will also be at the forefront of any measures undertaken to organize for a sustainable relationship with the natural environment. Studying how they are implementing practices whose aim is a sustainable co-existence with nature and how they represent these practices' interaction with nature, will provide an insight into how they understand the term sustainability and where this understanding may be taking us.

The primary object of study was an electronic text database of social and environmental reports and press releases describing how 25 different business corporations, dominated by the extractive MNCs previously mentioned, are managing for sustainability. In order to identify patterns in the selection and arrangement of words, very large volumes of text, ideally running upwards of millions of words, are necessary. Only then will individual words occur often enough in the database for usage patterns to become apparent. As one among many tools of discourse analysis, the corpus linguistic approach can provide findings at a macro-level. However, with such volumes of text to be analyzed, a computer search method has to be employed. The researcher must approach the corpus having worked out some hypothesis regarding what may (or may not) be found in the object of study. This procedure is described below.

Such words as targets, reporting, and controls, have long been key words in the discourse of modern business, and it is no surprise that these corporations take a similarly managerial approach in the implementation of their environmental commitments. Taking British Petroleum's annual sustainability report [8] as an example of the genre and word searching through the downloaded PDF document, one finds the word management in regular use. BP cares "about the safe management of the environment" (emphasis added) (p. 3). Drilling down from this overview perspective, the report includes representations of more specific aspects of managing the environment: 
"We take steps to assess and manage potential impacts on biodiversity, such as compiling a wildlife or biodiversity management plan or consulting with relevant experts and agencies to assess suitable actions" (emphasis added) (p. 45).

From the perspective of this article, it is also interesting to note how management, understood as a social, organizational process, combines the various objectives of the corporation in one system:

“BP's operating management system (OMS) (.) brings together BP requirements on health, safety, security, the environment, social responsibility and operational reliability, as well as related issues, such as maintenance, contractor relations and organizational learning, into a common management system" (emphasis added) (p. 25).

If we interpret this statement through the lens of environmental sociology, it would seem that BP's perception of the natural landscape is mediated through its operational management system (OMS). If the OMS includes a similarly managerial approach to sustainability as it does to the corporation's traditional, oil and gas activities, then we should expect it to contain targets for BP's sustainable relationship with the natural landscape as well as records of actual performance and accounts of the discrepancy-positive or negative-between the two. Making the safe assumption that the other so-called "green" corporations are also using the same managerial approach to their sustainability ambitions, it ought to be possible to find evidence in their textual representations that helps us to understand how nature is incorporated into their operating "management-for-sustainability" processes. In the remainder of this article, the terms green business and sustainable business are used simply as a convenient label for the corporations in this study. No normative claim regarding the achievement of sustainable goals is intended.

\section{Hypotheses}

In searching through the database of green business texts, therefore, the first hypothesis is that we should find words representing (i) the natural landscape and (ii) management processes. In addition to finding this evidence, a review of the words may provide clues to how the corporations perceive natural space through the lens of their operating management system. More significantly, the second hypothesis is that we should find textual evidence in which the corporations make representations of nature as the object of the sorts of processes of monitoring, reporting and control that one associates with a typical operational management system e.g., words from category (i) ought to appear as objects of verbs in category (ii).

The computer-based process of searching for particular words can, of course, only identify the presence of particular textual signs. The move from a word-understood purely as a textual signifier-to meaning is a necessarily interpretive process in which ambiguity can exist and must be resolved by human intervention. The linguistic evidence presented in the findings section contains no greater interpretive intervention than such avoiding of ambiguities.

In the final section, however, and responding to the call of this special issue, the "linguistic discourse" presented in the findings is interpreted within the context of corporate "managing-for-sustainability" practice. The article suggests how this social process influences corporate perceptions and understandings of the natural landscape.

\section{Methodological Rationale: A Theory of Words, Meaning, and Practice}

The theoretical underpinning for the interpretation of the findings brings together a theory of words, meaning and, most importantly, practice, which corresponds closely with Hajer's [9] understanding of discourse:

"Discourse is here defined as a specific ensemble of ideas, concepts, and categorizations that are produced, reproduced and transformed in a particular set of practices and through which meaning is given to physical and social realities" (emphasis added) (p. 44). 
His understanding of discourse contextualizes its ideas within certain actions and he argues that actors assign meanings to reality through social processes of practice (see also van Leeuwen [10]). Using Hajer's meaning, a particular discourse derives some of its uniqueness from the particular practices of the actors. Assuming that the extractive MNCs in this sample are approaching the challenge of sustainable development by implementing broadly similar practices, the ideas, concepts, and categorizations circulating within their discourse of sustainability will be broadly homogeneous. Some environmental scholars have already argued along these lines i.e., that terminology acquires meaning for a given group of practitioners through the operationalization of ideas [11,12]. Wenger's Communities of Practice [13] provides the central theory of meaning formation in this conceptualization of discourse and in this article. Sociolinguistics had previously linked language use to variables such as race, gender, age, and social class (see Labov [14], Macaulay and Trevelyan [15], and Wolfram [16]). The introduction of the concept of a community of practice, however, provides greater explanatory power in accounting for linguistic variation for example, between two ethnically British, middle-class, university-educated women, one of whom works, say, for British Petroleum while the other works for Greenpeace.

This latter point illustrates one implication of Hajer's "practice-dependent" understanding of discourse and offers one possible explanation for the often-observed phenomenon of conceptual fuzziness. Scholars in many different research environments have already pointed out the variation in meanings of particular terms or attempted normative definitions of key terminology [17-22]. Such fuzziness is not necessarily undesirable. The term sustainable development has been an extremely powerful driver of change, partly perhaps because its fuzziness has enabled it to appeal to a broad constituency of opinion. This article takes no normative stance on what definition should be assigned to the term. Neither, however, does it ignore the plasticity of some so-called sustainability discourse. Milne, Kearins, and Walton [23] (see also [24]) is an example of scholarship that deconstructs the discourse of self-styled sustainable business, by drawing attention to the intellectual inconsistencies that lie within the rhetorically-persuasive representations. In my reading of green business discourse, it is the more general statements-often delivered by the CEOs and/or the communications departments and often focused on goals, values, principles, or the future- that are most prone to this sort of fanciful sustainability discourse. Such discourse needs critical examination with a view to exposing its inconsistencies.

Increasingly, therefore, I have turned my attention to the nuts and bolts of the environmental management reports as a more reliable representation of what the corporation is doing. I concede that the corporations are making only partial representations of a much more complicated reality and that their decision what to represent and what not to represent is, most probably, weighted by instrumental interests. However, I think the language representations of practice are sincere albeit partial, attempts by the corporation to describe its reality.

Returning to the relationship between words and meaning, the second theoretical assumption of this article is that the meaning a community of practice associates with a word is reflected in the way in which the community uses the word. This position belongs to theory of language in use. The chronology in the study, as well as the associated development of theories of language in use, can be traced through Firth [25], Austin [26], Searle [27], and Halliday [28]. In parallel with the development of computing power in the later decades of the 20th century, corpus linguistics-the study of authentic texts or speech acts made by language communities-demonstrated, using very large quantities of text, that "meaning can be associated with a distinct formal patterning" [29] ((p. 6); see also Stubbs [30]). Thus, we have a three-way correlation in which the patterns of wording found in the texts of green business correlate with their organizational practices which, in turn, provide us with insights into the meaning which this group of social actors assigns to a particular word. One can identify both how green businesses are starting to practice sustainability and how they understand the term. 


\section{Method}

A more comprehensive account of the method can be found in previously published work [31,32] as, in the interests of brevity, just a brief overview is provided here. The selection criterion for what qualified as a British sustainable corporation was public membership of the World Business Council for Sustainable Development [33] and/or the UN Global Compact [34]. The first stage of the methodology was to build a database of texts that were representative of this community of practice and this was done by copying material down from the websites of the 25 businesses identified and saving it as txt files. In searching for distinctive patterns of wording in a body of texts, it is necessary to have a point of comparison and two references were set up. The first was publically available; the British National Corpus (BNC) [35]. BNC had several advantages as a benchmark. First, it was created by a group of highly-respected project partners, that included the British Library Research and Development Department, Oxford University Computing Services, Lancaster University, Oxford University Press, and Longman Group Ltd. Second, since one of its design goals was to construct a language corpus typical of British English, it provided a very good match for British sustainable businesses; national differences in the usage of the English language could be eliminated as a possible variable. A third advantage with the BNC was its ready availability. Finally, its very large size, 90 million words, provided confidence that it was representative of typical English, against which other databases could be compared.

The second point of comparison was a database composed of texts written by British social and environmental NGOs; 37 in total. In designing language databases that are to be compared, there are two mutually exclusive design objectives which must be reconciled as best one can. On the one hand, it is important that each body of texts is representative of the organizations that have provided the material. On the other hand, one wants to be able to compare the texts of the two databases, with a view to saying something interesting about them. If the communities of practice that have produced the text have very different representations of experience, then one runs the risk of merely demonstrating that different people talk about different things. The compromise solution was to define, in advance of the text selection activity, what ideational content I was looking for in order for a text to be downloaded into its respective database (see Brown [31] for a more detailed treatment of this process).

The PC program I used is called Wordsmith and is marketed by Oxford University Press [36]. The author of the software has published work that describes the linguistic phenomena which Wordsmith can identify [37]. There are also many previous studies that have used a similar keyword approach to that presented in this article [38-41]. In its first processing of the texts of the two communities-sustainable businesses and the environmental NGOs-it made a list of words that appeared in each of the two sample databases, ranking them in order of frequency. A moment's reflection is all that is necessary to realize that the most frequently used words in any wordlist are ones that we all use: "the, and, a, of, but" etc. and that these simple frequency-based word lists were of no value. However, Wordsmith then compared the two frequency-based word lists in turn with the corresponding reference list for the benchmark of "typical English" provided by the BNC, which also ranks words such as "the, and, a, of, but" etc. as the most frequent. This first comparison procedure generated a list of statistical keywords, ranking highest those words that appeared much more frequently in the green business and environmental NGO word lists than when they were used in the "typical English" of the BNC.

The first running of this process produced two keyword lists in which the representation of sustainability management was recognizable. However, Wordsmith is simply a very fast counting machine and, lacking any form of human intelligence, it records the appearance of absolutely everything in the texts. Consequently, this first processing included keywords that were statistically key to these environmental reports but not semantically significant to the process of identifying the representations of managing-for-sustainability practice. A cleaning up procedure was necessary in order to remove different categories of these uninformative keywords. Examples included proper 
nouns (Shell, Rio Tinto, GreenPeace, Africa, US, Doha), units of measurement (tonnes, GWH, litres), products and materials (gasoline, platinum, bauxite), acronyms (ACCP, WBCSD), and terms referring to the internal organization of reports (appendix, pdf, section). The top 20 key words used by the green businesses in their representations of management-for-sustainability practice are presented in Table 1 to give an impression of the results from this mechanistic process. The Wordsmith software generates the keyness value shown in the table. It is an indicator of how much more frequent the usage of a word is, compared with its usage in the benchmark database. The value 1.0 would indicate that it is no more frequent, so one can see that keyness values in the tens of thousands indicate that these particular terms are used massively more often by sustainable business than is the case for "typical English".

Table 1. The top twenty one-word keywords used by sustainable business.

\begin{tabular}{cccccc}
\hline \multicolumn{6}{c}{ Sustainable Business-the Top 20 One-Word Keywords } \\
\hline $\mathbf{N}$ & Keyword & Keyness & $\mathbf{N}$ & Keyword & Keyness \\
\hline 1 & ENVIRONMENTAL & $50,282.01$ & 11 & ENVIRONMENT & $17,173.10$ \\
2 & BUSINESS & $33,236.84$ & 12 & BIODIVERSITY & $17,137.79$ \\
3 & ENERGY & $32,561.70$ & 13 & COMPANIES & $16,551.74$ \\
4 & SUSTAINABLE & $28,694.50$ & 14 & DEVELOPMENT & $15,605.07$ \\
5 & EMISSIONS & $27,957.12$ & 15 & GLOBAL & $15,575.64$ \\
6 & EMPLOYEES & $21,345.17$ & 16 & REPORT & $15,331.68$ \\
7 & SAFETY & $21,059.48$ & 17 & STAKEHOLDERS & $15,162.41$ \\
8 & MANAGEMENT & $20,525.46$ & 18 & GROUP & $14,986.09$ \\
9 & WASTE & $19,852.47$ & 19 & CORPORATE & $14,716.54$ \\
10 & PERFORMANCE & $19,044.42$ & 20 & OPERATIONS & $14,448.74$ \\
\hline
\end{tabular}

Table 1 presents just the top 20 keywords of green business in a list that extends to several hundred whose keyness is statistically very significant. For example, the 500th most key word for sustainable business: wetlands, had a keyness of over 1000 in comparison with the "typical English" of the BNC. Using the same process, I also generated keyword lists for the top 100 two-word and top 50 three-word keywords. The top 20 of these keywords are presented in Table 2.

Table 2. The top twenty two- and three-word keywords used by sustainable business.

\begin{tabular}{cccccc}
\hline \multicolumn{7}{c}{ Sustainable Business-the Top Twenty Two-Word and Three-Word Keywords } \\
\hline $\mathbf{N}$ & Keyword & Keyness & $\mathbf{N}$ & Keyword & Keyness \\
\hline 1 & SUSTAINABLE DEVELOPMENT & $18,026.69$ & 11 & GROUP COMPANIES & 4885.16 \\
2 & HEALTH AND SAFETY & 9373.65 & 12 & HIV AIDS & 4822.87 \\
3 & CLIMATE CHANGE & 8229.32 & 13 & CORPORATE SOCIAL & 4781.19 \\
4 & ENVIRONMENTAL PERFORMANCE & 7138.26 & 14 & ENVIRONMENTAL AND SOCIAL & 4558.15 \\
5 & CORPORATE RESPONSIBILITY & 7077.07 & 15 & BEST PRACTICE & 4237.95 \\
6 & ENVIRONMENTAL MANAGEMENT & 6598.33 & 16 & MANAGEMENT SYSTEMS & 4156.79 \\
7 & BUSINESS PRINCIPLES & 6256.01 & 17 & CORPORATE SOCIAL RESPONSIBILITY & 4134.68 \\
8 & GREENHOUSE GAS & 5405.60 & 18 & NATURAL GAS & 4090.75 \\
9 & ENERGY EFFICIENCY & $5316, .6$ & 19 & RESPONSIBILITY REPORT & 3804.73 \\
10 & SOCIAL RESPONSIBILITY & 5283.72 & 20 & HUMAN RIGHTS & 3798.92 \\
\hline
\end{tabular}

At this point in the method, the search technique changed from Wordsmith's efficient but mechanistic process to a humanly slow, hopefully intelligent and certainly interpretive approach. These lists of the top 500 one-word, top 100 two-word and top 50 three-word keywords of green business and the environmental NGOs became the objects of study for identifying groups of words that shared certain semantic similarities, some of which I report in the findings.

The first hypothesis that I proposed involved representations of (i) the natural landscape and (for green business) (ii) representations of managing for sustainability in such locations. The first semantic search, therefore, was to look for words that made representations of some aspect of the 
natural landscape. Some of the words were easily identifiable—forest, for example-whereas others with a more ambiguous meaning were checked for their intended meaning. In order to do this, Wordsmith generated a list of 20 randomly picked occurrences of the word. From a careful reading of the context in which it was used, I interpreted the meaning. Using this technique, for example, the word growth was not included in the semantic field of representations of natural space because it was clear that business used the word exclusively as a representation for economic expansion. Pursuing evidence to test part (ii) of the first hypothesis, the second search was to look for words that made representations of a process of management that might be applied to the natural landscape. As an aid to identifying the sorts of words for which I would be searching, I prepared a schematic describing the different stages of a process of operational management-for-sustainability. The schematic evolved out of my reading various environmental reports that were a part of the database the circular process of monitoring, reporting, analyzing, deciding, planning, and implementing is presented in Figure 1. It functioned as a sort of "semantic template" as I searched through the two- and three-word keywords of sustainable business looking for representations of a process of management.

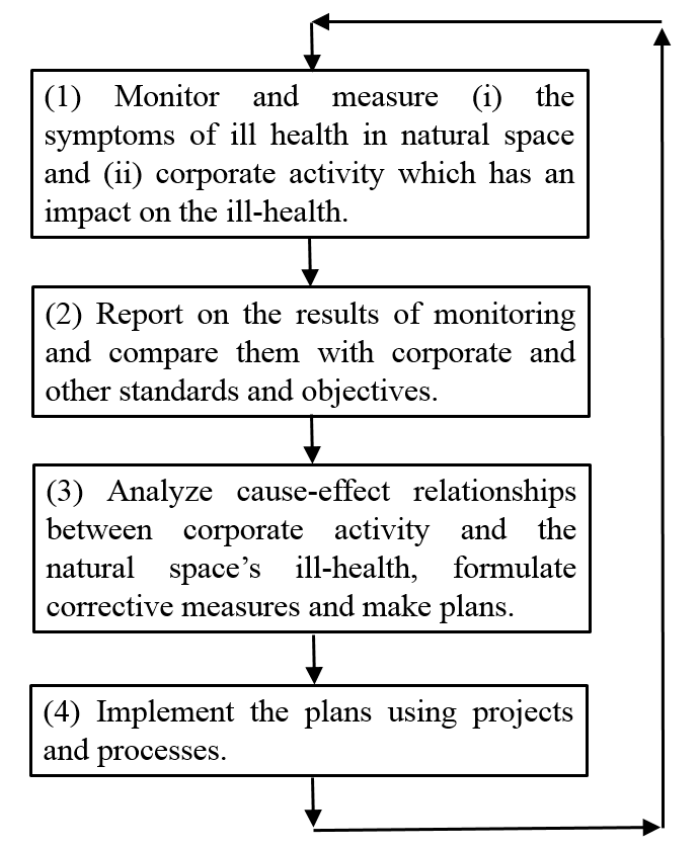

Figure 1. A process of operational management for sustainability.

Summarizing, this procedure identified words in the green business database representing (i) the natural landscape and (ii) processes of operational management. The logical place to look for evidence that sustainable businesses might have started the process of managing the natural landscape, was where the words in category (i) functioned, grammatically as objects of the processes in (ii). Wordsmith has a function that enables one to study this phenomenon. It picks out 20 random occurrences of the same operator-selected word from the entire database. For each of the 20 occurrences it extracts the string of text in which the word appears with a cut off of 200 characters of text on each side of the selected word. This is normally sufficient contextualizing text for the operator to check for any possible ambiguities and confirm the writer's intended meaning. This process is discussed further in the findings in which just such a problem is illustrated.

\section{Findings}

These findings provide a response to the hypotheses and empirical questions which sought linguistic evidence showing how green businesses relate to natural space as they attempt to manage 
for sustainability. Here I present three distinct vocabularies of keywords from the text databases and then demonstrate the textual interaction of two of them within the corporations' texts.

\subsection{Finding One: Two Different Representations of Natural Space}

From a comparison of the top 500 one-word keywords of the two communities of practice, I found that the environmental NGOs use two different types of words to represent nature, whereas the corporations use just one. For want of a better term, the NGOs use a "natural" (sic) vocabulary to represent the natural landscape. These are words that make a direct reference to some physical—fleshy or fibrous - part of nature. Examples in their top 500 keywords (see Table 3) include, crops, forest, soil, whale, and villagers.

Table 3. "Natural" representations of the natural landscape among the top 500 one-word keywords of the environmental NGOs, ranked in descending "keyness".

\begin{tabular}{ccccc}
\hline CROPS & LIVELIHOODS & WATER & FOODS & MARINE \\
\hline FARMERS & POOREST & PEOPLE'S & FEED & VILLAGERS \\
FOOD & CROPS & SOIL & WHALE & REINDEER \\
FOREST & PEOPLES & MAHOGONY & RAINFOREST & PLANTS \\
POOR & RURAL & WHALES & RAIN & WOMEN`S \\
FORESTS & SEED & COUNTRYSIDE & BEET & POULTRY \\
\hline
\end{tabular}

Reading Wordsmith's randomly generated occurrences of such words in the texts in which they appear, one gains the immediate impression of environmental NGOs that position themselves in specific places in the natural landscape with the intention of bearing witness on their condition and the threats to which they are exposed.

Such words cannot be found in the top 500 keywords of green business. The texts of their environmental reports do make representations of natural spaces. However, they do this with what I would dub a "vocabulary for being managed". Examples of these terms are areas, biodiversity, community, habitats, and site (see Table 4).

Table 4. A "vocabulary for being managed"—representations of nature among the top 500 one-word keywords of both the environmental NGOs and green business (ranked alphabetically).

\begin{tabular}{cccc}
\hline AREAS & COMMUNITY & HABITATS & RESOURCES \\
\hline BIODIVERSITY & ENVIRONMENT & HEALTH & SITE \\
COMMUNITIES & HABITAT & RESOURCE & SITES \\
\hline
\end{tabular}

These words are the preferred textual representations of the natural landscape for sustainable business. The great advantage of them, from a green business point of view, is that they lend themselves to being defined and measured numerically. This enables information about the natural landscape to be incorporated into the operational management system. Although the preferred terms of sustainable business are abstractions of nature rather than the more immediate representations that the NGOs use, it is important to underline that a reading of the corporations' usage reveals that they are nonetheless concerned for the well-being of the natural landscape. I discuss in more detail the way in which businesses make use of this feature of their vocabulary in the interpretation and conclusions section.

\subsection{Finding Two: Sustainable Business Representations of Operational Management-For-Sustainability}

The second category of evidence in the first hypothesis was representations in the green business texts of business processes, whose goal, presumably, is the sustainable usage of nature. Accordingly, the second search I conducted among the keywords of sustainable business was for representations 
of some aspect of operational management. Examples from the top one-word keywords of green business that might represent operational management are reporting, plan, impact, and indicators. However, careful reading of the usage of these one-word keywords in their environmental reports, revealed that they normally occurred as part of two- or three-word units of meaning, e.g., environmental reporting, social impact, habitat action plan, and GRI indicators that I found in the top 150 two- and three-word keywords. I therefore transferred the search process to this list and found that 63-just under one half-might be placed in this "operational management-for-sustainability" category, shown in Table 5. In addition to the four keywords just mentioned, other examples included biodiversity action plans, environmental management system, frequency rate, and key performance indicators. I have deliberately included the last two examples because the terms frequency rate and key performance indicators, and many other of the examples, are representations that one could just as easily find in business-as-usual operational management systems.

Table 5. The two- and three-word keywords of sustainable business whose representation is a part of the process of operating management.

\begin{tabular}{|c|c|}
\hline ACTION PLAN & GOOD CORPORATE CONDUCT \\
\hline ACTION PLANS & GRI INDICATORS \\
\hline ANNUAL REPORT & HABITAT ACTION PLAN \\
\hline BEST PRACTICE & HIGH STANDARDS \\
\hline BIODIVERSITY ACTION & INJURY FREQUENCY \\
\hline BIODIVERSITY ACTION PLAN & INJURY FREQUENCY RATE \\
\hline BIODIVERSITY ACTION PLANS & INTERNATIONAL MARKETING STANDARDS \\
\hline BUSINESS CONDUCT & KEY PERFORMANCE \\
\hline BUSINESS PRINCIPLES & KEY PERFORMANCE INDICATORS \\
\hline CODE OF BUSINESS & LAWS AND REGULATIONS \\
\hline CODE OF CONDUCT & MANAGEMENT SYSTEM \\
\hline CONTINUOUS IMPROVEMENT & MANAGEMENT SYSTEMS \\
\hline CORPORATE GOVERNANCE & OBJECTIVES AND TARGETS \\
\hline CORPORATE RESPONSIBILITY & PERFORMANCE DATA \\
\hline CORPORATE RESPONSIBILITY REPORT & PERFORMANCE INDICATORS \\
\hline CORPORATE SOCIAL RESPONSIBILITY & PRODUCT STEWARDSHIP \\
\hline DOW JONES SUSTAINABILITY & REPORTING INITIATIVE \\
\hline ENVIRONMENT REPORT & RESPONSIBILITY REPORT \\
\hline ENVIRONMENTAL IMPACT & RISK ASSESSMENT \\
\hline ENVIRONMENTAL IMPACTS & RISK MANAGEMENT \\
\hline ENVIRONMENTAL MANAGEMENT & SAFETY MANAGEMENT \\
\hline ENVIRONMENTAL MANAGEMENT SYSTEM & SAFETY PERFORMANCE \\
\hline ENVIRONMENTAL MANAGEMENT SYSTEMS & SOCIAL IMPACT \\
\hline ENVIRONMENTAL PERFORMANCE & SOCIAL INVESTMENT \\
\hline ENVIRONMENTAL PERFORMANCE REPORT & SOCIAL PERFORMANCE \\
\hline ENVIRONMENTAL REPORT & SOCIAL REPORT \\
\hline ENVIRONMENTAL REPORT APPENDICES & SOCIAL REPORTING \\
\hline ENVIRONMENTAL SUSTAINABILITY REPORT & SOCIAL RESPONSIBILITY \\
\hline FREQUENCY RATE & SOCIALLY RESPONSIBLE \\
\hline GLOBAL COMPACT & SUSTAINABILITY REPORT \\
\hline GLOBAL REPORTING & SUSTAINABILITY REPORTING \\
\hline GLOBAL REPORTING INITIATIVE & \\
\hline
\end{tabular}

In order to validate hypothesis two, it was necessary to look for evidence that these operational management processes are being applied to the natural landscape rather than representing the business processes with which the green corporations manage their traditional operations. Wordsmith can generate many reports that each show different usages of words by a particular community of practice. The most important function with regard to the findings in this article is its ability to generate a randomly selected sample of lines of text in which a selected keyword appears. This allows the researcher to read authentic examples of the usage of the keyword by the community 
of practice. In the theoretical section, I made the case that the way in which a community of practice uses a word reflects the meaning that the community associates with it and further, that this meaning is a consequence of practice and then reflection and social negotiation about that practice. I present the findings from this search and an interpretation that connects word usage with meaning and meaning with practice in the next section.

\subsection{Finding 3: Operational Management of the Natural Landscape}

The findings presented from the green business database are of (i) a "vocabulary for being managed" and (ii) a ubiquitous language of operational management. The logical place to look for evidence that sustainable businesses have started the process of managing the natural landscape was where the vocabulary for being managed takes center stage. If these terms function as the objects of the green business language of operational management-for-sustainability, then the findings support the second hypothesis. As described previously, Wordsmith provides a reporting function that can generate such text examples. Appendix contains four tables, each of which contains 20 randomly-selected text extracts from the green business database. The four words from the "vocabulary for being managed" that were selected for study are habitats, sites, areas, and communities. Once the operator has selected the central word and the amount of text to be retrieved either side of it, Wordsmith generates the reports itself. The only modifications I have made to these findings is to put the central term in boldface to draw attention to it, and to shade in grey the text that represents some aspect of the green business operational management-for-sustainability.

Reading of the tables for habitats, sites, and communities reveals that their intended representation is always of some natural, geographic space. However, the table for areas reveals this word's ambiguity; green business uses this term in two ways. In some examples, the referent is natural space; "Opencast mining areas and discard dump sites are key areas of focus" (Table A3, line 15). In other lines the word's referent is an abstract aspect of corporate attention; "Where elements and indicators in the GRI are relevant to Rio Tinto, we aim to report against them. In other areas we have reported against indicators that are more relevant to driving performance improvements" (Table A3, line 9). From my reading of Table A3, I concluded that nine of the 20 usages of areas are references to the natural landscape. This means that Appendix contains 69 examples of such a representation.

These findings demonstrate that textual representations of an operational managementfor-sustainability are usually present to contextualize the abstract vocabulary of natural space. There are representations of monitoring and measuring the natural landscape; "Develop an information management system which records and manages improved grassland data alongside other priority habitats" (Table A1, line 10). There are representations of reporting and comparing the information with corporate or other standards; "An assessment of alignment against these three stages and against the individual process steps of AA1000 is made. In addition VeriSEAAR@ can highlight areas where improvement has been achieved" (Table A3, line 11). Planning for making improvements to natural space is very common; "Have Biodiversity Action Plans (BAPS) in place at all sites where Shell operates in areas of high biodiversity value" (Table A3, line 1). Finally, there are representations of the implementation of plans using projects and processes; "We carry out Social Impact Assessments (SIA) to identify potential impacts on communities and to develop strategies to manage these" (Table A4, line 17). From a close study of sustainable business' textual representations of practice, one can see that it is introducing business processes whose goal is the sustainable management of nature.

\section{Discursive Interpretation}

In this section, the linguistic findings are interpreted within corporate managing-forsustainability practice in an attempt to flesh out its discourse. First, however, I need to make explicit the conceptualization of business corporations which is assumed in this interpretation. I conceive of them as being the business processes which are managed by the corporation's officers. For example, I conceive of a sustainable MNC as a process engineer's technical drawings, dictating the material 
and energy flows from which useful products are synthesized from raw materials; or as the financial controller's spreadsheets modeling the flows of assets into, around and out of the $\mathrm{P}$ and $\mathrm{L}$ and balance sheet. In this particular understanding of the organization, free human agency and human moral consciousness have no role; the employees of the corporation are reduced to instruments who manage the execution of business processes. I shall return to this assumption in the closing section.

\subsection{The Vantage Point from Which One Views the Natural Landscape Affects Its Representation}

In their role of guardians of nature, the environmental NGOs are in the privileged position of being able to position themselves-rhetorically-within the natural landscape. From this local vantage point, they see the detail of the natural spaces and this accounts for representations such as crops, forest, soil, whale, and villagers that are reported in the findings. In the sustainability reports of green business, however, the natural spaces in which their operations are located are viewed from corporate headquarters, often on the other side of the globe. This affects the language of representation in two ways. First, there are so many natural spaces, corporate headquarters must aggregate them by making abstractions of their physical reality. Second, since the physical materiality of a particular location cannot be known by the corporation's senior management at first hand, a form of representation of the natural space must be chosen that communicates meaningful information to these senior officers. At present, the meaningfulness has to be quantifiable. This is a "linguistic" discourse that is understood within the corporation and connects with the next point.

\subsection{Centralized Management Systems Require Numbers to Be Able to Manage}

In order for a global enterprise to manage its far-flung operations effectively from $\mathrm{HQ}$, it has its own internal models of the different installations. For example, the mining company's primary concentrator, which operates in the sand dunes running along South Africa's Atlantic coast, is controlled from a head office in central London. Day-to-day operational control is under the local plant manager and her engineers, but she reports the key numbers back to London on a regular basis in a spreadsheet. These numbers provide senior management with a sufficiently detailed representation of the complex physical materiality of the primary concentrator. At HQ they are compared in the spreadsheet with the expected year-to-date numbers and any variations are analyzed before instructions are sent back to South Africa. In short, the corporation's productive installations are operationally managed from headquarters using numbers.

Confirming one of the conclusions of Bansal and Knox-Hayes ([42] p. 77), if the MNC now commits itself to becoming a sustainable $\mathrm{MNC}$, it is likely to utilize its existing management processes in its attempts to manage for sustainability. In order to be able to manage them, the natural spaces-just like the MNC's productive installations-need to be represented in a set of key numbers that can be recorded in a spreadsheet so that comparisons can be made between actual and expected year-to-date, variations analyzed, and new instructions issued to the local manager. This interpretation accounts for the second type of representation of nature that was presented in the findings; a vocabulary for being managed. Words such as habitats, sites, areas, and communities have the advantage — for an MNC — of being quantifiable.

Returning to the mining company's challenge, the unique physical materiality of the natural space around the primary concentrator is represented, for example, as a habitat. Within the MNC's corporate model, the habitat is "understood" by a selection of key measurements; its area, the air quality measured daily at specific GPS coordinates, a series of biodiversity indicators etc. These are measured, recorded in the spreadsheet and, along with the production numbers for the concentrator, communicated back to London where they can be analyzed, decisions made, instructions issued, and action taken. One way, then, in which green corporations relate to natural spaces in their managing-for-sustainability project, is by constructing representations of nature that can be incorporated within a spreadsheet. 
With its perception based on an admittedly limited range of indicators, green business is able to describe the health of a natural space. One might balk at the notion suggested in the previous section, that MNCs are engaging in a process of managing nature. However, such a response might be mitigated by changing the representation from the term management to nurturing or stewardship. Continued corporate practice and its study will help us understand which of the practices are desirable and clarify what meanings the green corporations are investing in sustainability through their actions.

\subsection{Incorporating the Local within the Global?}

The abstract "vocabulary for being managed" is not, necessarily, a sign that these global green businesses are wholly ignorant of the local natural landscape around their productive installations. Certainly, when examining the macro-level characteristics of their texts, I was unable to find natural language representations. However, they do occasionally focus their gaze on a particular, local, natural space. For example, in line 15 of the report for the usage of habitats (Table A1, Appendix), the MNC describes its "employment of two rangers to help protect and enhance the wildlife habitats at our Musselburgh and Valleyfield ash lagoons". Pursuing this line of inquiry, on the webpages of ScottishPower [43], there are several natural representations of specific plants and animals, which belong to a particular habitat; not enough to register at the macro-level among the sustainable corporations' keywords, but some nevertheless. This practice is an example of Crane et al.'s idea [44] of corporate ecological citizenship which "requires corporate managers to be "embedded" in local environments to foster sustainable behaviors" (p.95). The two rangers who are employed by ScottishPower to protect and enhance the wildlife habitats at the Musselburgh and Valleyfield ash lagoons might be considered as "embedded" in the ash lagoons. This idea raises the possibility that within an MNC, pockets of local sustainability practice might be established by the corporation.

Pursuing this idea further, one intuitive impression I have gained from reading the corporate environmental reports is of occasional sustainability projects that are spared from the "vocabulary-for-managing" representation. These projects appear to be characterized by their being selected and then presumably funded, from the very highest levels of the corporation. Another avenue for further research would be to test for the existence of such a category of project. The working hypothesis is that corporate managing-for-sustainability practice might be divided into different categories. One category, following the main findings of this article, could be called operational sustainability practice. These would be all of the practices that are the consequences of the green corporation seeking to maintain a sustainable balance between its particular business operations and the natural landscapes around them. Their representation in reports would be characterized by the managerial vocabulary presented in this article. A second category, which might be called intrinsic sustainability practice, would be interventions in natural space that were not necessarily related to specific business processes but which the MNC, nevertheless, wished to implement. The representations of these projects might not be reduced to a language that Bell and Morse [17] characterize as having "quantification at its heart" (p. 42). The study of such projects in managing-for-sustainability business practice might point the way to finding practices that can know the local natural landscape in a more holistic way than the managerial techniques that are in evidence in these findings.

In closing this interpretive section, I revisit my assumed conceptualization of an MNC as different business processes from which human agency and moral consciousness are absent. In this article, I have referred to nature, natural space, and the natural landscape while deliberately avoiding using the term place. Without wishing to appear to be summarizing a very large debate, one generally-agreed distinction between space and place is the role of human sense-making in the latter. Place "has a history and meaning. Place incarnates the experiences and aspirations of a people. Place is not only a fact to be explained in the broader frame of space, but it is also a reality to be clarified and understood from the perspective of the people who have given it meaning" ([45], p. 387). Following 
Tuan, and assuming the conceptualization of an MNC that I advanced at the start of this section, when the sustainable corporation implements its operational managing-for-sustainability practices, the best we can get is a mechanistic sensitivity to natural space. Some researchers have argued that one promising avenue towards sustainability is for global MNCs to make a transition towards a place-based sensitivity to the natural landscape [46]. The process of knowing place is a practice that I think belongs in the Milne and Gray project for growing ecological literacy [5]. My tentative response to this challenge is that the MNC needs to find a way in which its business processes merge with its human stakeholders' moral consciousness so that the corporation can truly be said to give meaning to natural spaces in the construction of meaningful places.

\section{Limitations and Future Research}

It is, perhaps, not surprising that some form of direct management of nature will be a part of the sustainability response by these natural resource extraction companies. It is harder to imagine that an international bank's environmental reports would have so much focus on managing natural space. Further work needs to be done to find out how generalizable these findings are.

A second limitation is that the companies that were selected to be representatives of sustainable business were selected, because they had made a commitment to working towards a sustainable future. Making a commitment to a goal, however, is not the same as successful, authentic practice. A great deal of research using different methodologies for measuring sustainability practice in different types of organizations must be done in order to test the managing-nature hypothesis.

The third limitation concerns a distinction between operational, as opposed to strategic, management processes. There is no space here to do more than point out the general organizational challenge of making connections between the two, both in theory and practice. Non-alignment between the corporation's strategic objectives and its Performance Management System (PMS) has been a recognized phenomenon in the literature for over 40 years [47]. Business-as-usual strategic goals are usually fairly easy to articulate, so the focus is normally on bringing the PMS into alignment with long term strategy. In contrast, managing-for-sustainability strategic models are, as mentioned in the introduction, only vaguely understood [6]. Recognizing that nature itself is in a constant state of flux, the likelihood is that long-term models of the sustainable firm will co-evolve with changing natural landscapes [48]. It is at this stage, therefore, very difficult to ascertain with certainty if the sort of findings identified in this article-where we are-help or hinder a corporation's transition to more strategically-sustainable forms of operation and organization.

Acknowledgments: The author would like to thank the academic editor, the editorial team and the two anonymous reviewers for their constructive criticism in the writing of this article.

Conflicts of Interest: The author declares no conflict of interest.

\section{Appendix}

\section{Representations of Operational Management of the Natural Landscape in the Texts of Sustainable Business}

On the following pages are four tables each containing 20 lines of text. For each table the same word selected from the vocabulary of being managed is centrally placed. The occurrences have been randomly extracted by Wordsmith from the texts of green business and the lines of text are sufficiently long to be able to make an informed interpretation of the context in which the particular term is used by the corporation concerned. The terms selected are habitats, sites, areas, and communities. 
Table A1. Habitats.

\begin{tabular}{|c|c|}
\hline Line & Extract from Texts of the MNCs with Keyword Habitats Placed Centrally \\
\hline 1 & $\begin{array}{l}\text { ss raising, action plan monitoring and audit. XXXXX Hare The XXXXX hare is found throughout Britain. It is mainly nocturnal and is generally found in } \\
\text { open grassland habitats with nearby woodland and hedgerows which provide resting places or "forms" during the day. The hare's diet consists mainly } \\
\text { of herbs and grasses in summer and }\end{array}$ \\
\hline 2 & $\begin{array}{l}\text { Spotted Flycatcher Muscicapa striata Action Plan 1. Introduction } 1.1 \text { The spotted flycatcher is a summer migrant to the UK. The species prefers habitats } \\
\text { of open woodland, hedgerows with mature trees, parkland and large gardens. The species feeds almost entirely on insects. } 1.2 \text { The spotted flycatcher } \\
\text { generally a }\end{array}$ \\
\hline 3 & $\begin{array}{l}\text { icroscopic plants and animals to larger species such as common frogs and dragonflies. In addition, standing open water habitats are commonly fringed } \\
\text { by important wetland habitats such as marshy and swamp, which are covered in a separate swamp and marsh Habitat Action Plan. This broad standing } \\
\text { open water Habitat Action Plan has been pr }\end{array}$ \\
\hline 4 & $\begin{array}{l}\text { nhance selected scrub habitats and create new scrub areas in appropriate locations with low current nature conservation particularly where these border } \\
\text { existing woodland habitats. WT ? ? ? ? ? } 4.2 \text { Action Potential Partners Year Meets Objective No. } 2003200420052006200720135.2 .4 \text { Develop generic } \\
\text { management prescri }\end{array}$ \\
\hline 5 & $\begin{array}{l}\text { Swamp And Marsh Habitat Action Plan 1. Habitat Description } 1.1 \text { The term "swamp and marsh" covers a range of wetland habitats where water is at or } \\
\text { near the ground surface for most of the year. Swamp and marsh vegetation tends to be associated with ponds, floodplains and lakesides. } 1.2\end{array}$ \\
\hline 6 & $\begin{array}{l}\text { ion plan is reviewed and updated. WT ? ? 4.3 5.4 Awareness 5.4.1 Produce an internal communication so that best practice for the conservation of } \\
\text { improved grassland habitats can be used by staff where they occur on site. WT ? ? 4.4 5.4.2 Make areas of improved grassland available for recreation } \\
\text { and amenity where this does not }\end{array}$ \\
\hline 7 & $\begin{array}{l}\text { ecological survey programme. WT ? ? ? 4.1 5.1.2 Develop an information management system which records and manages improved grassland data } \\
\text { alongside other priority habitats. WT ? 4.1 5.1.3 Implement data management system, recording improved grassland data and keep up-to-date as } \\
\text { appropriate. WT ? ? ? ? 4.1 5.1.4 Research }\end{array}$ \\
\hline 8 & $\begin{array}{l}\text { animals and provides corridors allowing dispersal and movement between other habitats. Such habitats are becoming increasingly valuable for wildlife, } \\
\text { as other grassland habitats are lost. } 2.2 \text { Current threats to the improved grassland habitat include: • Recreational pressure. • Adding nutrients through } \\
\text { leaving grass cuttings 'in-s }\end{array}$ \\
\hline 9 & $\begin{array}{l}\text { on the broadleaved woodland habitat action plan. LA, WT ? ? ? ? ? ? 4.4 5.4.3 Encourage appropriate public access for study and enjoyment of broadleaf } \\
\text { woodland habitats. WT ? ? ? ? 4.4 5.4.4 Publish results of broadleaved woodland habitat action plan. - ? ? ? ? ? 4.4 6. Partners EN-English Nature } \\
\text { LA- }\end{array}$ \\
\hline 10 & $\begin{array}{l}\text { cological survey process. WT ? ? ? 4.1 5.1.2 Develop an information management system, which records and manages broadleaved woodland data } \\
\text { alongside other priority habitats. WT ? 4.1 5.1.3 Implement data management system, recording broadleaved woodland data and keep up-to-date as } \\
\text { appropriate. WT ? ? ? ? ? 4.1 5.1.4 Suppor }\end{array}$ \\
\hline
\end{tabular}


Table A1. Cont.

\begin{tabular}{|c|c|}
\hline Line & Extract from Texts of the MNCs with Keyword Habitats Placed Centrally \\
\hline 11 & $\begin{array}{l}\text { Partners Year Meets Objective No. } 2003200420052006200720135.1 \text { Data Collection and Information Management 5.1.1 Determine the extent of } \\
\text { broadleaved woodland habitats on all Biffa landholdings through the ecological survey process. WT ? ? ? 4.1 5.1.2 Develop an information management } \\
\text { system, which records and manages bro }\end{array}$ \\
\hline 12 & $\begin{array}{l}\text { ollection Site Management Monitoring Biodiversity Noxious Invasive Pest and Management and Audit Awareness Weeds Species Species SPECIES and } \\
\text { HABITAT ACTION. PLANS SPECIES HABITATS Skylark Woodland Nature Conservation Amenity Linnet Broadleaf Woodland Lowland Meadows } \\
\text { Improved Grassland XXXXX Hare Scrub Swamp and Mar }\end{array}$ \\
\hline 13 & $\begin{array}{l}\text { contribution Montgomeryshire Lake Vyrnwy-3 year population monitoring project undertaken with recommendations for future management of the } \\
\text { moorland and woodland edge habitats Peak National Park UDV-UK's first major re-introduction project launched in October } 2003 \text { Black Poplar LBAP } \\
\text { Target STW action STW contribution Derbyshire }\end{array}$ \\
\hline 14 & $\begin{array}{l}\text { ientific Interest (SSSIs) in our region. A number of these have been identified as being of European importance, and under EC Directives on the } \\
\text { conservation of natural habitats, flora and fauna, and birds, are nominated as Special Areas of Conservation (SACs) and Special Protection Areas (SPAs). } \\
\text { Special Areas of Conservation are strictl }\end{array}$ \\
\hline 15 & $\begin{array}{l}\text { ent Plans; and } \bullet \text { Implementation/asset management of the Management Plans. Generation supports the employment of two rangers to help protect and } \\
\text { enhance the wildlife habitats at our Musselburgh and Valleyfield ash lagoons. These rangers actively manage the reserves and help the public to enjoy } \\
\text { the facilities provided. A valuable bi }\end{array}$ \\
\hline 16 & $\begin{array}{l}\text { tegy is to minimise damage to biodiversity when we develop new projects or as part of our maintenance operations and to positively enhance our } \\
\text { landholding for species, habitats and heritage through measures such as our Rural Care Programme. ScottishPower aims to set a good example to other } \\
\text { energy users by actively seeking to minimise }\end{array}$ \\
\hline 17 & $\begin{array}{l}\text { graze on Bridger Coal Company's successful reclamation site, also located in Wyoming. PacifiCorp regards mining activities as an opportunity } \\
\text { proactively to enhance habitats. Taking part in biodiversity Our Environment Policy states that "... we will strive to continue to be regarded as a good } \\
\text { and trusted neighbour...". We engage ou }\end{array}$ \\
\hline 18 & $\begin{array}{l}\text { tishPower Environmental Performance Report 2003/04 Performance Review Our strategy for the management of biodiversity issues is to minimise } \\
\text { impact, positively enhance habitats, ensure that planned restoration enhances habitat and species where environmental impact is unavoidable and } \\
\text { contribute to biodiversity processes such as Local }\end{array}$ \\
\hline 19 & $\begin{array}{l}\text { into sites in ten countries started the BirdLife International/Rio Tinto partnership. The organisations share the aim of enhancing the conservation of birds } \\
\text { and their habitats as a means of contributing to sustainable development. The fourth annual Rio Tinto mine site birdwatching events organised by } \\
\text { BirdLife and Rio Tinto during } 200\end{array}$ \\
\hline 20 & $\begin{array}{l}\text { y five of the world's people rely on plants for primary health care, and plants help regulate our climate and bind our soils. They provide food, fibres, } \\
\text { timber, fuel and habitats for the wildlife, birds and insects that keep our fragile ecosystem in balance. Our Investing in Nature programme, through } \\
\text { Botanic Gardens Conservation Internat }\end{array}$ \\
\hline
\end{tabular}

Note: Processes of Managing Shaded in Grey. 
Table A2. Sites.

\begin{tabular}{|c|c|}
\hline Line & Extract from Texts of the MNCs with Keyword Sites Placed Centrally \\
\hline 1 & $\begin{array}{l}\text { ified to the International Standards Organisation's ISO } 14001 \text { environmental management systems standard by the end of } 2003 \text {. At the end of } 2001 \\
\text { over a quarter of our sites were certified. We have a team of experts who provide specialist environmental help and guidance to our manufacturing } \\
\text { plants throughout the world on issues rang }\end{array}$ \\
\hline 2 & $\begin{array}{l}\text { l efficiency of our manufacturing operations, and to incorporating environmental factors in the design and re-design of our } \\
\text { products-eco-innovation. We now have } 103 \text { sites certified to the international environmental management standard ISO } 14001 \text {. Our goal is to have } \\
\text { all our lead sites certified by 2003. For more information see th }\end{array}$ \\
\hline 3 & $\begin{array}{l}\text { ISO } 14001 \text { by the end of 2003. During 2002, a further } 23 \text { sites were certified, but } 20 \text { certified sites were closed or divested. At the end of } 2002 \text { we had } \\
114 \text { certified sites. We are continuing with the certification of individual sites but we are likely to fall short of } 100 \% \text { certification of our lead sites by } \\
\text { end } 2003 \text {. This is large }\end{array}$ \\
\hline 4 & $\begin{array}{l}\text { lection and reporting of environmental performance data via a global electronic system. Highlights for } 2004: \bullet 100 \% \text { of sites reported environmental } \\
\text { data } \bullet 98.6 \% \text { of sites reported on all key environmental parameters, apart from COD } \bullet 93.4 \% \text { of sites reported COD data } \bullet \text { following feedback from } \\
\text { the business, the pro-forma used for }\end{array}$ \\
\hline 5 & $\begin{array}{l}\text { ncy in manufacturing Environmental impact data In addition to reducing our impact per tonne of production, in } 2004 \text { the total environmental } \\
\text { impact of our manufacturing sites decreased for most of our key performance indicators. Unilever manufacturing performance 2000-2004: trends in } \\
\text { absolute load to the environment } 000102030423\end{array}$ \\
\hline 6 & $\begin{array}{l}\text { in } 2001 \text { and made additional commitments with regard to protected areas in 2003, including a commitment not to explore or drill for oil and gas in } \\
\text { natural World Heritage Sites (see Shell and protected areas) and in } 2005 \text { developed a Biodiversity strategy through to } 2010 \text { (see our Plans for } 2005 \text { ). } \\
\text { The Shell Group Biodiversity Standard We }\end{array}$ \\
\hline 7 & $\begin{array}{l}\text { Year Meets Objective No. } 200320042005200620072013 \text { 5.2.4 Ensure that common frog management prescriptions are included in Biodiversity } \\
\text { Management Modules for sites where the species occurs. WT ? ? ? 4.2 5.3 Monitoring and Audit 5.3.1 Develop a monitoring protocol for common } \\
\text { frogs on Biffa sites. WT, LA, HCT ? 4.3 5.3. }\end{array}$ \\
\hline 8 & $\begin{array}{l}\text { s Year Meets Objective No. } 200320042005200620072013 \text { 5.2.4 Develop generic management prescriptions to improve scrub areas for biodiversity } \\
\text { across all Biffa sites. WT ? 4.2 5.2.5 Ensure that scrub management prescriptions are included in Biodiversity Management Modules for sites where } \\
\text { the habitat occurs. WT ? ? } 4.2\end{array}$ \\
\hline 9 & $\begin{array}{l}\text { Meets Objective No. } 200320042005200620072013 \text { 5.2.5 Develop generic management prescriptions to improve lowland meadow areas for } \\
\text { biodiversity across all Biffa sites whilst retaining any amenity features. WT ? 4.2 5.2.6 Ensure that lowland meadow management prescriptions are } \\
\text { included in Biodiversity Management Modules for si }\end{array}$ \\
\hline 10 & $\begin{array}{l}\text { ected sites. EN, WT, UNI ? ? ? ? ? 4.2 5.2.5 Develop generic management prescriptions to improve eutrophic standing water areas for biodiversity } \\
\text { across all Biffa sites. WT ? 4.2 5.2.6 Ensure that eutrophic standing water management prescriptions are included in Biodiversity Management } \\
\text { Modules for sites where it occurs. WT? }\end{array}$ \\
\hline
\end{tabular}


Table A2. Cont.

\begin{tabular}{|c|c|}
\hline Line & Extract from Texts of the MNCs with Keyword Sites Placed Centrally \\
\hline 11 & $\begin{array}{l}\text { treatment sites, almost doubling existing capacity. Case study: Minworth Sewage Treatment Works package, GasSim, for calculating methane gas } \\
\text { emissions from landfill sites. Mitigation To mitigate our environmental impacts we are concentrating on our most significant emissions relating to } \\
\text { energy use and transport. Energy managemen }\end{array}$ \\
\hline 12 & $\begin{array}{l}\text { s up. This reflects improvements in reporting quality. One incident required regulatory notification but the Company has had no prosecutions or } \\
\text { fines. }{ }^{*} \text { EMS-number of sites certified to ISO } 14001 \text { has remained at } 9 \text { with all sites aiming to be certified by } 2006 .{ }^{*} \text { External benchmarking- the } \\
\text { business increased its score in the Business i }\end{array}$ \\
\hline 13 & $\begin{array}{l}\text { taken for project staff in order to increase environmental awareness and use of PEA checklist. Implement contaminated land risk ranking system, } \\
\text { targeting high risk sites for investigation. Undertake environmental initiatives which support the UK Biodiversity Plan. Monitor agreed } \\
\text { environmental mitigations for construction activ }\end{array}$ \\
\hline 14 & $\begin{array}{l}\text { cies, habitats and heritage. This involves the following concrete activities: } \bullet \text { Ensure our actions do not cause significant adverse effects on the } \\
\text { biodiversity of the sites within which we operate. } \bullet \text { Where features of strategic biodiversity importance occur on our larger land holdings, to protect } \\
\text { this biodiversity and contribute to }\end{array}$ \\
\hline 15 & $\begin{array}{l}\text { ween the two wetlands. Mondi is a dedicated supporter of the Natural Heritage Programme and is proud to be a part of this worthy programme. } \\
\text { The Mondi Natural Heritage Sites are very valuable for the conservation of biodiversity but they also play a vital role in education and recreation. }\end{array}$ \\
\hline 16 & $\begin{array}{l}\text { it is our intention to implement consistent guidelines for the preparation of these reports. Local site reports detailing our environmental } \\
\text { performance at } 60 \text { operating sites are also published on our website (page 64). These are currently prepared in accordance with the ISO } 14001 \\
\text { terminology. In } 2005 \text {, we intend to review the format of } t\end{array}$ \\
\hline 17 & $\begin{array}{l}\text { Caspian and Mediterranean, one of the issues studied was how the region's cultural heritage should be managed. Surveys of the proposed route } \\
\text { identified approximately } 500 \text { sites of potential heritage interest. More detailed investigations identified appropriate measures for each site, } \\
\text { including surface investigations, trial pits, full excav }\end{array}$ \\
\hline 18 & $\begin{array}{l}\text { ween the two wetlands. Mondi is a dedicated supporter of the Natural Heritage Programme and is proud to be a part of this worthy programme. } \\
\text { The Mondi Natural Heritage Sites are very valuable for the conservation of biodiversity but they also play a vital role in education and } \\
\text { recreation. ion. }\end{array}$ \\
\hline 19 & $\begin{array}{l}\text { MONDI NATURAL HERITAGE SITES ? Mondi Forests, ? PO Box 37 Johannesburg 2000, ? Tel +27 } 116470400 \text { ? Fax +27 } 116470568 \text { ? a member of } \\
\text { Anglo American plc group Mondi Ltd. Bookings or enqui }\end{array}$ \\
\hline 20 & $\begin{array}{l}\text { for community benefi t. BIODIVERSITY Biodiversity action plans in place Anglo American has set targets for the development of biodiversity } \\
\text { action plans (BAPs) at all sites }\end{array}$ \\
\hline
\end{tabular}

Note: Processes of Managing Shaded in Grey. 
Table A3. Areas.

\begin{tabular}{|c|c|}
\hline Line & Extract from Texts of the MNCs with Keyword Areas Placed Centrally \\
\hline 1 & $\begin{array}{l}\text { ojects that are employed to protect biodiversity and sensitive environments. 2. Have Biodiversity Action Plans (BAPs) in place at all sites where } \\
\text { Shell operates in areas of high biodiversity value. Related target: * By end } 2005 \text { a clear understanding of what a High Biodiversity Value Areas } \\
\text { (HBVA) means for Shell. * Per } 1 \text { January }\end{array}$ \\
\hline 2 & $\begin{array}{l}\text { to renovate flood plain habitats north of the landfill. Meanwhile, sheep graze on the restored sections of the landfill close to the site's boundaries. } \\
\text { Non-operational areas are progressively restored to grassland. Rob Sanders Registration Number UK-S-0000019 Restored area on Redhill landfill } \\
\text { site t w e n t y I SLE OF W I G H T Th }\end{array}$ \\
\hline 3 & $\begin{array}{l}\text { wider aims and will seek out opportunities to create local nature reserves and publicly accessible green space, joining together with others where } \\
\text { practical. In urban areas we will assess the potential for planting and landscaping schemes that will enhance biodiversity, create green corridors, } \\
\text { stepping stones and havens for wildlife. }\end{array}$ \\
\hline 4 & $\begin{array}{l}\text { nt techniques for standing open waters at selected sites. EN, WT, UNI ? ? ? ? ? 4.2 5.2.6 Develop generic management prescriptions to improve } \\
\text { standing open water areas for biodiversity across all Biffa sites. WT ? 4.2 5.2.7 Ensure that standing open water management prescriptions are } \\
\text { included in Biodiversity Management Modules }\end{array}$ \\
\hline 5 & $\begin{array}{l}2 \text { Action Potential Partners Year Meets Objective No. } 200320042005200620072013 \text { 5.2.5 Develop generic management prescriptions to improve } \\
\text { running water areas for biodiversity across all Biffa sites. WT ? 4.2 5.2.6 Ensure that running water management prescriptions are included in } \\
\text { Biodiversity Management Modules for s }\end{array}$ \\
\hline 6 & $\begin{array}{l}\text { thours each year. An assessment of Sagit's ice cream factory in Caivano near Naples also identified areas where energy could be saved, and a } \\
\text { system for targeting these areas and monitoring progress has been set up. This resulted in a reduction in total energy use at Caivano of } 8.7 \% \text { up to } \\
\text { the end of 2003, compared with 2001. The amount o }\end{array}$ \\
\hline 7 & $\begin{array}{l}\text { rs, using the new Reputation Tracker survey (page 11). Respondents were asked to assess Shell's overall "environmental responsibility" and our } \\
\text { performance in specific areas (e.g., minimising impacts from our operations, offering cleaner fuels and developing renewable energy). } \\
\text { Environmental responsibility was found to be one of the top }\end{array}$ \\
\hline 8 & $\begin{array}{l}\mathrm{h} \text { our European emissions reporting requirements and adds consistency across our reporting. We are pleased that ScottishPower continues to make } \\
\text { progress in a range of areas. This is reinforced by the variety of awards and recognition we have accepted from our stakeholders and peers, many of } \\
\text { which are mentioned in this report. We als }\end{array}$ \\
\hline 9 & $\begin{array}{l}\text { activities incorporate the principles outlined by the GRI. Where elements and indicators in the GRI are relevant to Rio Tinto, we aim to report } \\
\text { against them. In other areas we have reported against indicators and elements that are more relevant to driving performance improvements within } \\
\text { our business. In addition to this Group level }\end{array}$ \\
\hline 10 & $\begin{array}{l}\text { dership Survey in the website for more details. We monitor the questions employees put to senior managers through the QandA pages on myGSK } \\
\text { to ensure we pick up potential areas of concern. We also track readership of news stories on myGSK to help improve the relevance and interest of } \\
\text { the content. www.gsk.com-GlaxoSmithKline Corporate }\end{array}$ \\
\hline
\end{tabular}


Table A3. Cont.

\begin{tabular}{|c|c|}
\hline Line & Extract from Texts of the MNCs with Keyword Areas Placed Centrally \\
\hline 11 & $\begin{array}{l}\text { e Social Report. An assessment of alignment against these three stages and against the individual process steps of AA1000 is made. In addition } \\
\text { VeriSEAAR@ can highlight areas where improvement has been achieved, or areas for further improvement in the future. There is more information } \\
\text { at the Bureau Veritas website www.bureauveritas.co.u }\end{array}$ \\
\hline 12 & $\begin{array}{l}\text { e areas. (e.g., IUCN protected area categories 1-4, world heritage sites, biosphere reserves). While a small number of companies operate facilities in } \\
\text { or near protected areas, no impacts have been determined. www.bat.com/socialreport APPENDIX A A4 www.bat.com/socialreport APPENDIX A } \\
\text { EN26 Changes to natural habitats resulting from a }\end{array}$ \\
\hline 13 & $\begin{array}{l}\text { place in environmentally sensitive areas. Some are officially protected, but many are not. BP believes it is for governments to decide whether } \\
\text { sensitive or protected areas should be open to development and, if open, what measures should be taken to protect them. We will operate in } \\
\text { sensitive areas only if we are convinced we can proper }\end{array}$ \\
\hline 14 & $\begin{array}{l}\text { ase; helping them to become more competitive at home and in global markets. In addition, we also invest in community investment programmes: } \\
\text { focusing our support in three areas: enterprise development, education and energy access. More directly, our business benefits our employees and } \\
\text { shareholders. In } 2004 \text { we paid wages and salaries, soc }\end{array}$ \\
\hline 15 & $\begin{array}{l}\text { 1 environmental management plans. This involves the wise use of natural resources and, where possible, the prevention of adverse environmental } \\
\text { impacts. Opencast mining areas and discard dump sites are key areas of focus. ACSA's approach to implementing this policy includes: } \\
\text { _ environmental baseline studies; _ environmental impact ass }\end{array}$ \\
\hline 16 & $\begin{array}{l}\text { fatalities are most likely to occur have been identified as falls of ground, moving machinery and transportation. Coal dust and possible methane } \\
\text { explosions also remain areas of high focus. ACSA's Lost-Time Injury Frequency Rate (LTIFR), which reflects the number of shifts lost due to injuries } \\
\text { for every 200,000 hours worked, includes i }\end{array}$ \\
\hline 17 & $\begin{array}{l}\text { er, one of the three operation areas N A M A K W A S A N D S F O O T P R I N T } 200218 \text { Africa in October 2002; • The Company as a whole and } \\
\text { all three operational areas attained NOSA Platinum } 5 \text { Star gradings on the NOSA Integrated SHE System in October 2002; • 47 workplace sections } \\
\text { within the Company have worked } 2909 \text { days wit }\end{array}$ \\
\hline 18 & $\begin{array}{l}\text { om specialist environmental consultants and Anglo Coal Environmental Services, provide us with the practical means to retain or enhance the } \\
\text { biodiversity of sensitive areas managed by our operations. Actions for biodiversity management that meet the requirements of the 'White Paper on } \\
\text { Conservation and Sustainable Use of South Africa }\end{array}$ \\
\hline 19 & $\begin{array}{l}\text { cts which are critical to AWG's sustainability performance. At present, the systems for data collection are not sufficiently robust to allow complete } \\
\text { reporting for all areas. AWG should focus on embedding its targets into all business units and on developing complementary management systems } \\
\text { to enable reporting against these targets. T }\end{array}$ \\
\hline 20 & $\begin{array}{l}\text { o produce a strengthened health and safety policy, with particular emphasis on improvements to standards and responsibilities. Further updating } \\
\text { of Group-wide standards in areas of potential risk identified at the conference is being carried out by seven working groups. This work will be } \\
\text { completed by the end of } 2003 \text { and will ensure that b }\end{array}$ \\
\hline
\end{tabular}


Table A4. Communities.

\begin{tabular}{|c|c|}
\hline Line & Extract from Texts of the MNCs with Keyword Communities Placed Centrally \\
\hline 1 & $\begin{array}{l}\text { civil society groups and government authorities and begin building partnerships that strengthen the long term sustainability of community } \\
\text { projects". Social Benefiting communities Nigeria update Community agitation for greater and rapid development of the Niger Delta region remains } \\
\text { high. The Nigerian government has taken steps toward }\end{array}$ \\
\hline 2 & $\begin{array}{l}\text { ustainable energy future. It has two core objectives: reducing environmental impact of fossil fuel use, and increasing access to sustainable energy, } \\
\text { particularly in poor communities of developing countries. It's an innovative effort, which allies social investment with a business approach and } \\
\text { develops projects that build on Shell's unique }\end{array}$ \\
\hline 3 & $\begin{array}{l}\text { upport the government's target of achieving a } 20 \% \text { reduction in } \mathrm{CO}_{2} \text { emissions by } 2010 \text {. The Trust is delivering investment in new renewable } \\
\text { projects of benefit to local communities enabled by customers who pay a small premium through our Green Tariff. Further information about our } \\
\text { Green Energy Fund or our other activities within the c }\end{array}$ \\
\hline 4 & $\begin{array}{l}\text { west Territories of Canada. No one was relocated for this development and detailed agreements have been established during the five year } \\
\text { consultation with neighbouring communities and approval process. • Sustainable urban land development: Kennecott Utah Copper (KUC), holds } \\
\text { land surrounding the mine in excess of its needs and there i }\end{array}$ \\
\hline 5 & $\begin{array}{l}\text { included in the performance section, page 22. Commitment: "Develop measurement tools that reflect the effectiveness of our contribution of } \\
\text { resources to neighbouring communities and of our relationship with the communities". Rio Tinto has signed a memorandum of understanding } \\
\text { with Warwick University Corporate Citizenship Unit, UK, }\end{array}$ \\
\hline 6 & $\begin{array}{l}\text { inues, with completion targeted for early } 2005 \text {. Establishment of an effective process to address the compensation claims improved relationships } \\
\text { between KEM and local communities and has enabled the implementation of a number of important community development and capacity } \\
\text { building initiatives which seek to secure sustainable solut }\end{array}$ \\
\hline 7 & $\begin{array}{l}\text { SandE reports Does your company have any statistics on implementation of community involvement policies? }{ }^{*} 2004 \text { SD Review: results data is } \\
\text { provided for contributions to communities, contribution to the economy and input/output measurements * See also all local SandE reports Do you } \\
\text { have any information on your land agreements? }{ }^{*} 2004 \mathrm{~S}\end{array}$ \\
\hline 8 & $\begin{array}{l}\mathrm{n} \text {, particularly for children from disadvantaged backgrounds, is the central aim of our education initiatives. Community Encouraging our } \\
\text { employees to engage with the } \\
\text { communities in which we do business is a vital part of CSR. FAQs Read the frequently asked questions about Corporate Social Responsibility. CSR } \\
\text { report Download the la }\end{array}$ \\
\hline 9 & $\begin{array}{l}\text { sources in an efficient manner, we will move further down the track of sustainable and responsible manufacturing. This is good for shareholders, } \\
\text { employees, communities and the environment-and hence good for our business. This will continue to be a focus in the future". } 13 \text { the assessment } \\
\text { of the health, safety (excludin }\end{array}$ \\
\hline 10 & $\begin{array}{l}\text { ganization and the World Bank to local schools and community-based organisations. Where possible, we ensure that our programmes are } \\
\text { sustainable and can be repeated in communities with similar needs. Our programmes comprise major initiatives in public health, support for } \\
\text { education, product donations, and support for employee involve }\end{array}$ \\
\hline
\end{tabular}


Table A4. Cont.

\begin{tabular}{|c|c|}
\hline Line & Extract from Texts of the MNCs with Keyword Communities Placed Centrally \\
\hline 11 & $\begin{array}{l}\text { cal libraries and providing them with book vouchers Powergen Environment Fund The Powergen Environment Fund provides } £ 50,000 \text { a year to } \\
\text { environmental projects in local communities. In } 2001 / 2002,16 \text { projects received support, including hedge planting, nature trail improvements and } \\
\text { composting schemes. The fund was launched in } 1999 \text { and i }\end{array}$ \\
\hline 12 & $\begin{array}{l}\text { ommunity, sensitive to all the impacts of our business. SC: The pressures you've mentioned have derived from regulators, government, } \\
\text { stakeholders, shareholders, local communities and environmental impacts—all influencing the strategic decisions that you make. Do you think } \\
\text { your stakeholders recognise just how many factors you are havi }\end{array}$ \\
\hline 13 & $\begin{array}{l}\text { s we are not unique. But China's social needs remain vast. No individual company is likely to make a huge difference by itself. But by working with } \\
\text { government, partners, communities and other stakeholders, and by sustaining the commitment over time, foreign investors can have an impact } \\
\text { within their areas of expertise. And it is for that } r\end{array}$ \\
\hline 14 & $\begin{array}{l}\text { ESPONSIBILITY REPORT } 20042 \text { Chief Executive's statement continued BG Group seeks to identify and manage potential impacts. We believe that, } \\
\text { where relationships with communities are built on openness and trust, projects can proceed with mutual benefit. BG Group respects the right of our } \\
\text { host countries to decide their own developme }\end{array}$ \\
\hline 15 & $\begin{array}{l}\text { ternity pay, paternity leave and adoption leave, including for same-sex couples. Corporate Social Responsibility } 30 \text { INTRODUCTION SERVING } \\
\text { AUDIENCES IN BUSINESS COMMUNITIES THE ENVIRONMENT FEEDBACK The corporation won the } 2004 \text { Zayed International Prize for } \\
\text { Environment, with The World series Earth Report- }\end{array}$ \\
\hline 16 & $\begin{array}{l}\text { included in the performance section, page 22. Commitment: "Develop measurement tools that reflect the effectiveness of our contribution of } \\
\text { resources to neighbouring communities and of our relationship with the communities". Rio Tinto has signed a memorandum of understanding } \\
\text { with Warwick University Corporate Citizenship Unit, UK, f }\end{array}$ \\
\hline 17 & $\begin{array}{l}\mathrm{t} \text {, human rights and social investment. UNDERSTANDING OUR IMPACTS AND RESPONSIBILITIES We carry out Social Impact Assessments } \\
\text { (SIA) to identify potential impacts on communities and to develop strategies to manage these. We also engage with local, national and international } \\
\text { non-governmental organisations (NGOs). Understanding the } \mathrm{p}\end{array}$ \\
\hline 18 & $\begin{array}{l}\text { ment and capacity building in Northern KwaZulu-Natal. The organisation's ongoing training initiatives, allied to relationship building and a deep } \\
\text { understanding of the communities in which it operates, forms the basis of the development of sound small businesses in these rural areas. These } \\
\text { include small-scale farming projects and rur }\end{array}$ \\
\hline 19 & $\begin{array}{l}\text { reports to the Board of directors. 7. Stakeholder engagement: Promote and maintain open and constructive dialogue and good working } \\
\text { relationships with employees, local communities, regulatory agencies, business organisations and other affected and interested parties, to increase } \\
\text { knowledge and enhance mutual understanding in matters o }\end{array}$ \\
\hline 20 & $\begin{array}{l}\text { tening Stakeholder engagement We engage widely with a range of stakeholders to ensure our CSR programme addresses their key concerns. This } \\
\text { includes investors, NGOs, communities, suppliers, customers and employees. Last year we made a commitment to complete an independent } \\
\text { review of our Group-level stakeholder engagement }\end{array}$ \\
\hline
\end{tabular}

Note: Processes of Managing Shaded in Grey. 


\section{References}

1. Dryzek, J.S. The Politics of the Earth: Environmental Discourses, 2nd ed.; Oxford University Press: Oxford, UK, 2005; p. 145.

2. Sustainability through the Lens of Environmental Sociology. Available online: http://www.mdpi.com/ journal/sustainability/special_issues/EnvironmentalSociology (accessed on 17 July 2015).

3. Gray, R.H.; Milne, M.J. Towards reporting on the triple bottom line: Mirages, methods and myths. In The Triple Bottom Line: Does It All Add Up?; Henriques, A., Richardson, J., Eds.; Earthscan: London, UK, 2004.

4. Gray, R. Is accounting for sustainability actually accounting for sustainability... and how would we know? An exploration of narratives of organizations and the planet. Account. Organ. Soc. 2010, 35, 47-62. [CrossRef]

5. Milne, M.J.; Gray, R.H. W(h)ither ecology? The triple bottom line, the global reporting initiative, and corporate sustainability reporting. J. Bus. Ethics 2013, 118, 13-29. [CrossRef]

6. Starik, M.; Kanashiro, P. Toward a Theory of Sustainability management: Uncovering and Integrating the Nearly Obvious. Organ. Environ. 2013, 26, 7-30. [CrossRef]

7. Zollo, M.; Cennamo, C.; Neumann, K. Beyond What and Why: Understanding Organizational Evolution towards Sustainable Enterprise Models. Organ. Environ. 2013, 26, 241-259. [CrossRef]

8. Building a Stronger, Safer BP. Available online: http://www.bp.com/content/dam/bp/pdf/sustainability/ group-reports/Sustainability_Report_2014.pdf (accessed on 17 July 2015).

9. Hajer, M.A. The Politics of Environmental Discourse: Ecological Modernization and the Policy Process, 1st ed.; Clarendon Press: Oxford, UK, 1995.

10. Van Leeuwen, T. Discourse and Practice: New Tools for Critical Discourse Analysis, 1st ed.; Oxford University Press: Oxford, UK, 2008.

11. Franceschi, D.; Kahn, J.R. Beyond Strong Sustainability. Int. J. Sustain. Dev. World Ecol. 2003, 10, $211-220$. [CrossRef]

12. Özkaynak, B.; Devine, P.; Rigby, D. Operationalising Strong Sustainability: Definitions, Methodologies and Outcomes. Environ. Values 2004, 13, 279-303. [CrossRef]

13. Wenger, E. Communities of Practice: Learning, Meaning, and Identity, 1st ed.; Cambridge University Press: Cambridge, UK, 1998.

14. Labov, W. The Social Stratification of English in New York City, 2nd ed.; Cambridge University Press: Cambridge, UK, 2006.

15. Macaulay, R.K.S.; Trevelyan, G.D. Language, Social Class and Education: A Glasgow Study, 1st ed.; University of Edinburgh Press: Edinburgh, UK, 1977.

16. Wolfram, W. A Sociolinguistic Description of Detroit Negro Speech, 1st ed.; Center for Applied Linguistics: Washington, DC, USA, 1969.

17. Bell, S.; Morse, S. Sustainability Indicators: Measuring the Immeasurable, 2nd ed.; Earthscan: London, UK, 2008.

18. Brand, F.S.; Jax, K. Focusing the meaning(s) of resilience: Resilience as a descriptive concept and a boundary object. Ecol. Soc. 2007, 12, 23-39.

19. Fergus, A.H.T.; Rowney, J.I.A. Sustainable Development: Lost Meaning and Opportunity? J. Bus. Ethics 2005, 60, 17-27. [CrossRef]

20. Hacking, T.; Guthrie, P. A Framework for Clarifying the Meaning of Triple Bottom-Line, Integrated, and Sustainability Assessment. Environ. Impact Assess. Rev. 2008, 28, 73-89. [CrossRef]

21. Hopwood, B.; Mellor, M.; O’Brien, G. Sustainable development: Mapping different approaches. Sustain. Dev. 2005, 13, 38-52. [CrossRef]

22. Waas, T.; Hugé, J.; Verbruggen, A.; Wright, T. Sustainable Development: A Bird's Eye View. Sustainability 2011, 3, 1637-1661. [CrossRef]

23. Milne, M.J.; Kearins, K.; Walton, S. Creating adventures in Wonderland? The journey metaphor and environmental sustainability. Organization 2006, 13, 801-839. [CrossRef]

24. Milne, M.J.; Tregidga, H.M.; Walton, S. Words not actions! The ideological role of sustainable development reporting. Account. Audit. Account. J. 2009, 22, 1211-1257. [CrossRef]

25. Firth, J.R. Papers in Linguistics 1934-1951, 1st ed.; Oxford University Press: London, UK, 1957.

26. Austin, J.L. How to Do Things with Words, 1st ed.; Oxford University Press: London, UK, 1962. 
27. Searle, J.R. Expression and Meaning: Studies in the Theory of Speech Acts, 1st ed.; Cambridge University Press: Cambridge, UK, 1979.

28. Halliday, M.A.K. An Introduction to Functional Grammar, 2nd ed.; Edwin Arnold: London, UK, 1994.

29. Sinclair, J. Corpus, Concordance, Collocation, 1st ed.; Oxford University Press: Oxford, UK, 1991.

30. Stubbs, M. Text and Corpus Analysis, 1st ed.; Blackwell Publishers Ltd.: Oxford, UK, 1996.

31. Brown, M. Managing Nature-Business as Usual: Patterns of Wording and Patterns of Meaning in Corporate Environmental Discourse; Acta Humaniora: Oslo, Norway, 2008.

32. Brown, M. A Methodology for Mapping Meanings in Text-based Sustainability Communication. Sustainability 2013. [CrossRef]

33. WBCSD. Business Solutions for a Sustainable Word. Available online: http://www.wbcsd.org/home.aspx (accessed on 17 July 2015).

34. UN Global Compact. Available online: https://www.unglobalcompact.org/ (accessed on 17 July 2015).

35. British National Corpus. Available online: http://www.natcorp.ox.ac.uk/ (accessed on 17 July 2015).

36. Wordsmith Tools. Available online: https://elt.oup.com/catalogue/items/global/multimedia_digital/ 9780194505161?cc=no\&selLanguage $=$ en\&mode=hub (accessed on 17 July 2015).

37. Scott, M.; Tribble, C. Textual Patterns: Key Words and Corpus Analysis in Language and Education, 1st ed.; John Benjamins Publishing Company: Amsterdam, The Netherlands, 2006.

38. Archer, D., Ed.; What's in a Word-List? Investigating Word Frequency and Keyword Extraction, 1st ed.; Ashgate Publishing: Farnham, UK, 2009.

39. Kemppanen, H. Keywords and Ideology in Translated History Texts: A Corpus-based Analysis. Across Lang. Cult. 2004, 1, 89-106. [CrossRef]

40. Rayson, P. From key words to semantic domains. Int. J. Corpus Linguist. 2008, 13, 519-549. [CrossRef]

41. Toolan, M. Values are Descriptions; or, from Literature to Linguistics and back again by way of Keywords. Belg. J. Engl. Lang. Lit. 2004, 1, 11-30.

42. Bansal, P.; Knox-Hayes, J. The Time and Space of Materiality in Organizations and the Natural Environment. Organ. Environ. 2013, 26, 61-82. [CrossRef]

43. ScottishPower. Available online: http://www.scottishpower.com/pages/reputation_and_sustainability.asp (accessed on 17 July 2015).

44. Crane, A.; Matten, D.; Moon, J. Ecological citizenship and the corporation: Politicizing the new corporate environmentalism. Organ. Environ. 2008, 21, 371-389. [CrossRef]

45. Tuan, Y. Space and Place: Humanistic Perspective. In Philosophy in Geography; Gale, S., Olsson, G., Eds.; D. Reidel: Dordrecht, The Netherlands, 1979.

46. Shrivastava, P.; Kennelly, J.J. Sustainability and Place-Based Enterprise. Organ. Environ. 2013, $26,83-101$. [CrossRef]

47. Skinner, W. Manufacturing-Missing Link in the Corporate Strategy. Harv. Bus. Rev. 1969, 47, 136-145.

48. Stead, J.G.; Stead, W.E. The Coevolution of Sustainable Strategic Management in the Global Marketplace. Organ. Environ. 2013, 26, 162-183. [CrossRef]

(C) 2015 by the author; licensee MDPI, Basel, Switzerland. This article is an open access article distributed under the terms and conditions of the Creative Commons by Attribution (CC-BY) license (http:/ / creativecommons.org/licenses/by/4.0/). 